\title{
4 From Research Funding to Public Relations
}

\author{
The Making of a Food Industry \\ Think Tank in 1970s France
}

\author{
Thomas Depecker, Marc-Olivier Déplaude, \\ and Nicolas Larchet
}

\section{Introduction}

More and more, the food industry is having to cope with attacks from the pseudo-scientific media, and all companies can do in response is report on their own works - the objectivity of which is challenged not only by consumers and the organizations that defend them, but also, sometimes, by public authorities. [...] In the work carried out by the Foundation and in its very existence, opinion makers and public opinion itself will find the reassurance that they need in the current climate of "consumerist" protest,

says the call to arms contained in a memo produced in March 1974 by the Fondation française pour la nutrition (French Nutrition Foundation, or FFN), an organization established the same year by several major companies and organizations in the French agri-food sector. Initially, this organization proposed to support existing research in the field of nutritional sciences and to participate in the dissemination of their results. However, it quickly appeared that the limited funds at its disposal did not allow it to compete with public support for research, in the manner of the large American foundations oriented toward medical research. Funded exclusively by professional organizations and companies, the FFN was not established as a tax-exempt foundation under French law, despite its name, but had the more limited status of a nonprofit association. Launched as a funding agency, it gradually developed as a place to meet and to produce expertise that would influence public debate in the manner of a "think tank". In the declaration of intent that accompanies its statutes, the FFN declared its "independence" and the "endorsement of scientific communities" to solve "the current problems of modern food and nutrition". With think tanks that were becoming autonomous at the same time in the United States, it shared an interstitial position between academic, political, economic, and media fields, which gave it 
the character of a hybrid organization whose success depended on its capacity to ensure that these sectors communicate with one another (Medvetz 2012).

Just as the most activist conservative think tanks came into being in the 1970s in the United States to counter the influence of radical intellectuals and social movements, the food company executives who created the Foundation wanted to compete with consumer associations on their own ground - that of information - but without appearing to do so. The period was indeed characterized by the development of consumer associations in France as a media power denouncing potentially harmful industrial products and practices but also as experts in regulatory battles (Chatriot 2006). Because they were compelled to mention the composition of foodstuffs on packaging from 1972 onward, food companies needed to convince the general public of the harmlessness of the ingredients and food additives they used. They therefore needed allies: recognized researchers or academics, who were the only people who could give their organization (a) an appearance of autonomy in terms of economic interests and (b) a guarantee of seriousness and scientificity to counter consumerist criticism.

In this chapter, we study how the FFN was progressively shaped into a think tank, from the very first meetings in 1972 to discuss its creation, through to 1982 when its operation and the orientation of its activities became stable. Our approach will consist in analyzing the successive negotiations that led to its creation, the tensions that divided its members, and the way in which they were resolved. ${ }^{1}$ In the first section, we will situate our approach more specifically within the academic literature on think tanks. Unlike the majority of works which analyze the public activities of think tanks, we will focus on their lesser known internal processes. The FFN will thus be analyzed as a "negotiated order", bringing together competing interests. In the second section, we will present consumer associations' critiques of the food industry in 1970s France, which led to the creation of the FFN in reaction to a controversy on cooking oils and food labeling. To appear as a neutral and scientific organization and not merely as food industry interest group, the FFN had to open its rank to academics: these "enrollment" strategies led to negotiations between academic and industrialists and will be discussed in the third section. In the final section, we will examine how the FFN reoriented its policies to engage in public relations and consumer information, after the departure of academics who hoped to use it as a funding agency.

\section{Think Tanks as Negotiated Orders}

The 1960s and 1970s were marked by a "deep crisis of legitimization of industrial activities" in Western societies (Boudia and Jas 2019, 53). Major social movements denounced the working conditions that corporations were forcing upon their employees, the impact of their 
activities and products on health and the environment, and more generally their alleged contribution to the well-being of the population. These movements, which led to the adoption of regulations that provided a tighter framework for economic activities than was hitherto the case, in turn led to major mobilizations by corporate actors (Vogel 1983; Chamayou 2018). Imitating the methods and strategies employed by their opponents, the initiators of these counter-movements engaged in various arenas: workplaces, courts, parliaments, administrations, the media, scientific communities, etc. This led in particular to the creation of new organizations including think tanks. They first developed in the United States and the United Kingdom before spreading to the rest of the world (Stone 2015). In France, they allegedly emerged during the late 1970s and early 1980s in organizations based within business, political, and administrative elites such as the La Boétie Institute and the Saint-Simon Foundation (Schwartz 2010).

For the most part, research on think tanks has focused on the dissemination of neoliberal doctrine in the field of economic policy and of neoconservative worldviews in foreign policy (Stone 1996; Denord 2002; Pautz 2012; Stahl 2016; Plehwe et al. 2020). More recent works have looked at organizations working on health and environmental risks, particularly those relating to economic sectors implicated in climate change (McCright and Dunlap 2003; Oreskes and Conway 2010). These works analyze think tanks as organizations that aim to influence public authorities in the field of ideas, using various strategies: the organization of events designed to bring together members of various elite circles (business leaders, academics, journalists, senior civil servants, politicians, etc.), publications (newsletters, journals, reports, policy briefs, etc.), and media interventions (Stone 2007). Although these strategies often have a long-term horizon, they can coexist with lobbying actions aimed at creating short-term effects on those in power (Caré 2010). Different notions have been used to characterize think tanks: "intermediaries" (James 1993), "border organizations" (Stone 2007), "transfer agencies" (Plehwe 2015), "brokers" (Schlesinger and Junqua 2012; Tchilingirian 2018), etc. They all stress the fact that networking and coalition-building activities constitute a fundamental aspect of how think tanks work.

Yet, these studies essentially focus on the public activities of think tanks and on their façades. They say little about their internal operation, the way their strategies are defined, and the nature of the relationships among their members. However, given their activities, think tank members generally come from different backgrounds (businesses, universities, public administrations, etc.). They have potentially conflicting interests, the convergence of which is by no means self-evident. Works produced by academics who are themselves employed by think tanks have raised this issue (Weaver 1989), but so far, it has not been explored to any great extent, even in research based on ethnographic observations or in-depth 
interviews with members of these organizations (Medvetz 2012; McLevey 2015; Shaw et al. 2015).

In the following sections, we will look at how an organization such as the FFN is built, bringing together individuals who do not all share the same interests and who do not all have the same expectations: the form of the organization, its operation, the orientation of its activities, and its budget are subject to negotiation. We analyze this organization as a "negotiated order" (Strauss et al. 1963; Fine 1984), i.e., a place and a product of continuous negotiation among its members. The outcome of each negotiation, whether or not it results in an agreement, determines the subsequent negotiation. This leads to an analysis focused on processes consistent with the interactionist tradition in sociology (Abbott 2001). The data available to us make it possible to accurately reconstruct these negotiation processes. This chapter is based on the archival records of the Fonds français pour l'alimentation et la santé (French Food and Health Fund, FFAS), an organization founded in 2010 as an offshoot of the FFN. They include all of the minutes of meetings of the Foundation's internal bodies since their creation: its Bureau, Board of Directors, Scientific Committee, and Communication Group. For the period 1972-1978, they also include minutes of working group meetings, summary notes, budget documents, correspondence, etc. In addition to these internal documents, we also analyzed the following Foundation publications: a monthly letter to its members (1976-1977), a quarterly newsletter, and an annual activity report from 1979 onward.

It was between 1972 and the early 1980s that the Foundation acquired the attributes that it would retain until the end of the 2000s. In studying this singular process, we will try to identify the typical problems encountered by organizations such as the FFN, which aim to enroll academics in the service of economic interests, while at the same time ensuring a certain autonomy in relation to the latter. Drawing from Callon and Law (1982), we consider "enrollment" as a negotiation process in which highly mobilized actors (in this case, food company executives) try to encourage other actors (in this case, academics) to take an interest in their organizational project. We will not therefore be analyzing the content of the FFN's policies and public output in any detail. We assume that in order to understand the scope of such content, one must first understand the social relations in which it was developed.

\section{A Counter-mobilization by the Agri-food Industry}

The Foundation's creation stemmed from the mobilization of certain large companies in the agri-food sector, in reaction to the rise of the consumerist movement. As David S. Meyer and Suzanne Staggenborg (1996) observed, one of the common characteristics of counter-movements is that they borrow certain features from the movements they oppose. This isomorphic process can be seen here. The mobilized executives wanted 
to create an organization that shared two features with consumer associations. Firstly, it had to produce analyses perceived as objective and disinterested, and the best guarantee of this would be the reputation of the researchers who participated in its work. Secondly, its analyses must be widely disseminated in the public arena. The creation of the Foundation was thus part of a broadening of the food companies' repertoire of actions, a broadening that led not only to the use of new strategies to defend economic interests but also to the invention of new organizational forms.

\section{An Industry on Thin Ice}

The rise of consumerist mobilizations in the 1970s was the result of several developments that affected Western societies during the postwar period. The second half of the 20th century was marked by an unprecedented increase in the worldwide production of chemical substances and by their penetration into a growing number of economic sectors (Boudia and Jas 2019). This process primarily concerned food and agriculture. Following the Second World War, there was a very rapid increase in the use of chemical products by farmers and stockbreeders (synthetic fertilizers, phytosanitary products, veterinary drugs, growth hormones, etc.) and by food-processing industries, particularly through the use of additives. This unprecedented development, supported by public authorities who promoted the production of cheap and abundant food, led to the industrialization of many foodstuffs (cheeses, cured meats, ice cream, bakery products, etc.) and to the arrival on the market of so-called new products (ready-made meals, powdered soups, commercially prepared desserts, etc.). These changes went hand in hand with a decrease in the time spent on shopping for food and preparing meals and an increase in the proportion of processed foods in total food spending (Besson 2008). Finally, food was more frequently sold in the form of self-service products in the supermarkets that appeared in the 1950s (Daumas 2006). Due to poor packaging regulations, buyers had to rely on the scarce information provided by labels in these new retail outlets.

These developments, which were not unique to France, were criticized by consumer associations and academics in industrialized societies as of the 1950s (Belasco 1989; Degreef 2019). They denounced the presence of an increasing number of new substances in foods sold commercially, the absence of information on labels, and potential health hazards. In France, this caused organizations to campaign for improved consumer information and to carry out comparative tests on retail products (Depecker and Déplaude 2017; Pinto 2018). Initially supported by public authorities, these organizations underwent significant change in the early 1970s, marked by a more critical stance toward industrial society and its consequences on health and the environment and by greater use of the mainstream media to force public authorities and manufacturers to take action. This development was to a large extent 
rooted in the powerful protest movements - environmental movements in particular - that developed in Western societies in the late 1960s and early 1970s. It was especially pronounced in France within the Union fédérale des consommateurs (Federal Consumers Union or UFC), which publishes the Que Choisir? magazine, the monthly circulation of which rose from 35,000 to 300,000 copies between 1971 and 1974. Inspired by the reflections put forward by American activist Ralph Nader, ${ }^{2}$ it regularly published articles denouncing the industrialization of agriculture and food processing. Many of the tests carried out for Que Choisir? related to food and were designed to identify the presence of additives (preservatives, antiseptics, antioxidants, colorants, flavor enhancers, etc.) and contaminants (pesticide or drug residues, heavy metals, asbestos, solvents, etc.) (see Table 4.1). Such substances were found in a wide range of products from cured meats to baby food. For UFC, "our food has become a poisoned feast. [...] We have been reduced to varying our

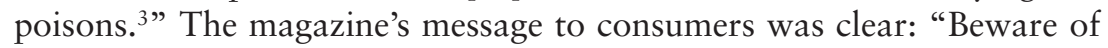
industrial products."

The organization of the first Salon des consommateurs (Consumer Trade Show) in Paris in October 1972, to which Ralph Nader was invited, was seen by many commentators as the expression of a new power with which food companies would have to come to terms. In the early 1970s, certain French food companies were caught up in a fierce controversy that had a significant impact on their understanding of this new power: the canola oil controversy (Bonneuil and Thomas 2009). Indeed, as from the 1960s, French producers decided to replace peanuts with canola in cooking oils, generally without informing consumers, using generic names such as "table oil" or "superior oil", etc. At the same time, however, scientific studies were suggesting that oil from the variety of canola cultivated at that time might present cardiovascular risk factors. Faced with the government's refusal to bring the results of this research to the attention of the general public, several academics and consumer associations seized upon the issue, which received extensive media coverage between April 1971 and July 1972. Sales of oils likely to contain canola fell. In June 1972, the company Lesieur \& Cotelle, which represented

Table 4.1 Food tests published by the Que choisir? magazine between 1961 and 1980

\begin{tabular}{lcc}
\hline & $1961-1970$ & $1971-1980$ \\
\hline Additives & 14 & 20 \\
Contaminants & 0 & 20 \\
Bacteriological analyses & 4 & 9 \\
Total & 18 & 49 \\
\hline
\end{tabular}

Interpretation: between 1961 and 1970, fourteen tests consisted in detecting and/or measuring the presence of additives in food. 
$50 \%$ of the cooking oil market in France, finally agreed with other oil companies to ban canola oil from their "superior oils". It was not until 1973, with the development of a new variety of canola, that the controversy finally died down, albeit not without serious economic and regulatory consequences concerning labeling. Indeed, the damage was already done. In 1972, a decree enforcing food companies to label the composition of foodstuffs, including additives, was promulgated.

\section{The "Foundation": An Institutional Formula}

In April 1972, when the canola oil controversy was still making the headlines, Lesieur \& Cotelle's Director of External Relations intervened at the general assembly of the Institut de liaisons et d'études des industries de consommation (Institute for Liaison and Studies of Consumer Industries, ILEC), an association of consumer goods manufacturers. ${ }^{5}$ He suggested creating a "joint laboratory that would make it possible to analyze products and thus respond to the comparative tests carried out by consumer unions". Five months later, he sent ILEC's General Manager, a former Unilever executive, a memorandum from Bernard Lesieur, scientific advisor to Lesieur \& Cotelle, sketching the outlines of a future "French Food Institute". In this note, Bernard Lesieur clarified and amended the initial project. He used the following observation as his starting point:

Today, we are seeing growing consumer awareness of health problems in general, and food-related in particular.

Given this state of affairs, food manufacturers must study, with even greater care, the ever-increasing number of medical issues relating to their products.

To achieve this, the food companies needed studies produced by "official research organizations, recognized as such". Yet the field of nutritional sciences was then occupied by several rival "schools", none of which carried "sufficient weight to provide an undisputed opinion on nutrition", which was deemed "quite regrettable". On the basis of discussions with the leaders of two of these "schools", Lesieur defended the idea that the future institute should "federate" the top academic research centers in the field of nutrition and coordinate their research programs. It would have two missions: firstly to define the programs and divide them among existing laboratories and secondly to "interpret the results [of these studies] in such a way as to be able to give an opinion that is as unquestionable as possible and that can, more particularly, stand up to consumer associations and the press". These activities would be mainly financed by membership fees paid by the Institute's member companies. For an additional fee, it could also carry out "confidential research" for companies.

Based on this memorandum, ILEC's Deputy General Manager set up a working group of executives from major agri-food and cosmetics 
companies (see Table 4.2). In total, eleven companies took part, most of them very large. ${ }^{6}$ Four were multinationals (Unilever, Nestlé, CPC International, and Pillsbury) represented by their French subsidiaries, and two were French conglomerates producing a wide range of products (BSN-Gervais-Danone and Générale alimentaire). They were represented by senior executives: of the twenty-seven executives attending (or invited to attend) the working group meetings, six were CEOs and at least thirteen others held senior management positions. In addition to these company executives, there were representatives from three professional organizations: ILEC, the Chambre syndicale de la conserve (French Canning Industry Union), and, above all, the Association nationale des

Table 4.2 The companies that attended the working group meetings that led to the creation of the FFN (1972-1974)

\begin{tabular}{|c|c|c|c|c|}
\hline Group & $\begin{array}{l}\text { Country of } \\
\text { origin }\end{array}$ & $\begin{array}{l}\text { Subsidiaries } \\
\text { represented }\end{array}$ & Area of activity & $\begin{array}{l}\text { Number of } \\
\text { meetings }\end{array}$ \\
\hline Nestlé & Switzerland & $\begin{array}{l}\text { SOPAD, } \\
\text { Guigoz } \\
\text { France }\end{array}$ & $\begin{array}{l}\text { Diversified food } \\
\text { products and } \\
\text { infant food }\end{array}$ & 8 \\
\hline $\begin{array}{l}\text { BSN-Gervais- } \\
\text { Danone* }\end{array}$ & France & $\begin{array}{l}\text { Evian-Fali, } \\
\text { Diépal }\end{array}$ & $\begin{array}{l}\text { Diversified food } \\
\text { products, dairy } \\
\text { products, and } \\
\text { infant food }\end{array}$ & 7 \\
\hline Lesieur & France & & $\begin{array}{l}\text { Cooking oil and } \\
\text { margarine }\end{array}$ & 7 \\
\hline Unilever & $\begin{array}{l}\text { Netherlands } \\
\text { and UK }\end{array}$ & $\begin{array}{l}\text { Astra-Calvé, } \\
\text { Thibaud- } \\
\text { Gibbs }\end{array}$ & $\begin{array}{l}\text { Diversified food } \\
\text { products, cooking } \\
\text { oil, margarine, and } \\
\text { cosmetics }\end{array}$ & 6 \\
\hline Bel & France & & Dairy products & 6 \\
\hline $\begin{array}{r}\text { Biscuiterie } \\
\text { nantaise }\end{array}$ & France & & Bakery products & 6 \\
\hline $\begin{array}{l}\mathrm{CPC} \\
\text { International }\end{array}$ & USA & $\begin{array}{l}\text { Société des } \\
\text { produits du } \\
\text { maiis }\end{array}$ & $\begin{array}{l}\text { Corn and starch } \\
\text { products }\end{array}$ & 4 \\
\hline $\begin{array}{l}\text { Générale } \\
\text { alimentaire }\end{array}$ & France & & $\begin{array}{l}\text { Diversified food } \\
\text { products }\end{array}$ & 1 \\
\hline Pillsbury & $\begin{array}{l}\text { United } \\
\text { States }\end{array}$ & Gringoire & $\begin{array}{l}\text { Diversified food } \\
\text { products and } \\
\text { bakery products }\end{array}$ & 1 \\
\hline L'Oréal & France & & Cosmetics & 1 \\
\hline
\end{tabular}

Interpretation: between 1972 and 1974, the Nestlé group was represented at or invited to seven working group meetings.

Source: FFAS archives.

*BSN and Gervais-Danone merged in 1973. 
industries agricoles et alimentaires (National Association of Agricultural and Food Industries, ANIAA), representing all French agri-food companies in their dealings with public authorities.

Robert Féron, Scientific Director for Astra-Calvé, a Unilever subsidiary producing oils and margarines, was put in charge of the group's work. Approximately ten meetings were held between October 1972 and March 1974. During these meetings, the companies agreed that the future organization should have a certain degree of operational autonomy from the funders. This was seen as an indispensable condition if academics were to agree to join. The fact that academics were to be fully involved in the activities and management of the organization was considered to be a matter of vital importance, for two reasons. Firstly, as stated in a memorandum presented to the working group in March 1973, "endorsement from scientific communities ensures [the] credibility [of the future organization] among opinion leaders - practitioners, the press, teachers, consumer organizations ... and public opinion itself". Secondly, the organization would also be a means, as stated in the same memorandum, of socializing academics into "the concerns of food companies, because researchers are often unaware of the latter's needs and constraints, despite the fact that they are often at the origin of legal and regulatory requirements". In other words, the support of academics would enable them to counterbalance the positions taken by consumer associations while at the same time making experts more sensitive to their interests when they were called upon to give their opinion on draft regulations brought about by the mobilization of these same associations.

To this end, the members of the working group agreed on "a formula: [that of the] foundation ${ }^{7}$. The institutional formula of the nonprofit foundation made it possible to clearly distinguish between the future organization and other outlets that were explicitly designed to defend the food industry's economic interests. ${ }^{8}$ Officially, the foundation's mission would be to support academic research in nutrition and not to attack consumer associations. A memorandum drafted at the beginning of 1973 states this very explicitly (underlined in the original text):

The idea of creating a foundation comprised of both food companies and academics is making headway. [...]

Official objective: to encourage nutrition research by providing the world of research with the funding it currently lacks and ensuring a close working relationship between industry and science.

Hidden objective: to be able to respond to pseudo-scientific attacks from consumerists with works of research carried out by an unchallengeable foundation (which must therefore be of sound reputation).

The decision to set up a foundation was undoubtedly influenced by the existence of similar organizations abroad: certain food companies were indeed aware of the existence of the British Nutrition Foundation, created 
in 1967, from which they drew inspiration when drafting their articles of association. The autonomy of the future organization also needed to be established through the creation of two bodies: the Foundation's Board of Directors, composed of equal numbers of academics from the public sector and food company representatives, and its Scientific Committee, also made up of equal numbers of academics from the public sector and executives from the food companies' research and development (R\&D) departments. These bodies were also to be chaired by leading academics.

\section{Enrolling Academics}

From this point on, the major challenges for the members of the working group were to convince academics to join the Board of Directors and the Scientific Committee of the Foundation and to contribute to its activities (symposia, publications, etc.). Food companies needed academics recognized by their peers and, if possible, by wider audiences. In this section, we will examine the enrollment strategies that the food companies employed, along with the negotiations that ensued. Finally, in the last section, we will show how, with the support of certain academics, the senior executives gradually gained the upper hand in steering the Foundation's activities. This process might be characterized as a process of alignment (Blumer 1962) at the end of which some of the academics were forced to comply with the food company executives or else give way to other colleagues who better shared the latter's positions. ${ }^{9}$

\section{A Two-Stage Enrollment Process}

The manufacturers chose to contact a small number of academics in important institutional positions in the field of nutritional sciences, in the hope that if they joined the project, their colleagues would be more inclined to follow suit. This was Robert Féron's main task. As the scientific director of a major subsidiary of the Unilever multinational, Féron had access to a vast network of contacts within the field of food research, particularly in relation to lipids. First of all, he contacted two academics. The first was Henri Bour, professor of medicine and head of department at Hôtel-Dieu, a major Parisian university hospital. The second, Jean Trémolières, was professor of biology at the Conservatoire national des arts et métiers (National Conservatory for Arts and Crafts, CNAM), a prestigious establishment for the training of engineers and technicians for industry, created during the French Revolution. Both men had devoted their careers to the institutionalization and recognition of nutrition as a scientific discipline, the former in a university hospital environment and the latter in public research. Henri Bour was the first Parisian doctor to hold a university chair in "human nutrition". With one of his students, he turned his hospital department into a leading center for the treatment of obesity and nutritional disorders. Before joining CNAM, Jean Trémolières 
had been in charge of the "nutrition" department at the Institut national d'hygiène (National Institute of Hygiene ${ }^{10}$ ) and of the body responsible for defining the French government's research policy in this field. In addition to these positions of power, Henri Bour and Jean Trémolières both helped create bodies defending and representing the interests of their discipline. In 1963, they cofounded a learned society in the field of nutrition and dietetics. They were also involved in activities of popularization: Bour in partnership with a major Parisian science museum and Trémolières by publishing books for the general public and making regular appearances on radio and television.

Having obtained their agreement to join the Foundation, Robert Féron then contacted other academics, using his preexisting networks: of the eight academics who were members of the foundation's scientific committee as of 1974, five were members of the Groupe lipides et nutrition (Lipids and Nutrition Group, GLN), an association created in 1963 on the initiative of Unilever and other margarine manufacturers with the aim of supporting research on lipids, and of which Féron was a member. ${ }^{11}$ When necessary, Féron pulled out all the stops: no less than four people, including Féron himself and the CEO of the French subsidiary of the Guigoz group (owned by Nestle since 1971), visited the home of Hugues Gounelle de Pontanel, to rally him to the cause. Considered by the food company executives as a "great name in research ${ }^{12}$ ", Gounelle de Pontanel was a member of the French academy of medicine and President of the Conseil supérieur d'hygiène publique de France (French Higher Council of Public Hygiene), two bodies that the government was obliged to consult in relation to any new regulations concerning food products.

The food company executives' efforts were highly successful. In total, they managed to convince fifteen academics to sit on the Foundation's Board of Directors and on its Scientific Committee. With an average age of fifty-seven, most of them were well known and held important positions of institutional power. The majority ran research laboratories, hospital departments, or even major higher education and research institutions. They were recognized experts in their respective fields (nutritional sciences, pharmacology, and toxicology) and were solicited in regulatory arenas. The Foundation had thus enrolled members or managers from the "Food" section of the French Higher Council of Public Hygiene, such as Yves Raoul and Hugues Gounelle de Pontanel. Some of them were internationally recognized experts, such as toxicologist René Truhaut, who invented the notion of "acceptable daily intakes", which was adopted by international organizations responsible for the regulation of toxic substances. Four of the most elderly were also members of the French academies of sciences, medicine, and pharmacy. The people chosen to lead the Foundation or its bodies had received many such marks of recognition. The Foundation and its Board of Directors were chaired by Georges Champetier, a recognized specialist in polymer chemistry, director of a prestigious engineering school, and a member 
of the French academy of cciences. He was assisted by Hugues Gounelle de Pontanel, the Foundation's Vice President, and Jean Trémolières, Chairman of the Scientific Committee. This success came at a price: as courtesy and networking were often not enough to persuade the scientists they needed, food company executives had to engage in lengthy negotiations concerning the original project.

\section{Negotiated Enrollment}

Some academics went through tough negotiations with the food companies as soon as the future Foundation's draft articles of association were drawn up. In April 1973, ILEC and ANIAA put an initial version before the working group headed by Robert Féron. This document was sent to Jean Trémolières, who asked for several changes to be made. The most important of these related to the budget of the future organization which, according to ILEC and ANIAA's draft articles of association, should not exceed 250,000 francs per year. This is what Trémolières wrote to them in June 1973:

Human nutrition will disappear within ten years if we maintain the present system of recruitment by [public research organizations]. The current number of "public" academics in human nutrition is in the region of 60 . Public recruitment of technicians has been zero for the past five years and that of academics stands at less than one per year.

The sine qua non condition, i.e., the primary imperative for research groups to make an informed decision to accept cooperation [with the future Foundation], is that the initial funding serves to ensure the salaries of four researchers at an increasing rate of $25 \%$ per year for six years. [...]

Groups that are not initially assigned a researcher will receive an allocation for the additional intellectual work that will be requested of them. [...]

The first instalment needed at the outset is therefore 300,000 francs, with a forecast increase of $25 \%$ per year for three years.

Jean Trémolières pointed out that additional costs, in the order of 80,000 francs per year, would have to be provided for the day-to-day operation of the Foundation (salaries of the director and a secretary and sundry expenses). Within three years, the Foundation's scientific budget would be in the region of 500,000 francs per year, plus operating costs. Yet Trémolières did not ask solely for a significant increase in the future Foundation's resources. He also demanded that, excluding operating costs (reduced to a minimum), the money the food companies paid should only be used to finance research and not to fund other actions, particularly in the fields of information and communication. These demands led 
to "serious objections" from ANIAA's chairman. Henri Bour also had serious misgivings, as handwritten notes taken at a meeting of the ILEC working group reveal:

[Bour] willingly accepts to participate but does not wish the Foundation to merely be a means of financing certain research centers [...]. The Foundation's action should be extended to other areas relating to nutrition: teaching, information, documentation, regulation. [...] He strongly criticizes Trémolières' current attitude.

Nevertheless the food company executives accepted Trémolières' demands, in part: the future Foundation's provisional budget was increased to 500,000 francs per year, 300,000 francs of which was to be used to fund research and postdoctoral fellowships and 200,000 francs for operating costs. This was less than the amount Trémolières had been requesting, but far more than what the executives had initially planned to spend. Moreover, no specific budget was set aside to finance information and communication activities.

How might we explain the adoption of this compromise in Jean Trémolières' favor? First and foremost, even after the increase, the Foundation's budget remained modest compared to the resources available to the companies associated with the ILEC working group. Secondly, his wish that the Foundation's activities should focus on supporting research and not on information and communication activities was supported by other researchers contacted by the food company executives. Finally, Jean Trémolières not only held a central position in the field of nutritional sciences in France, but his reputation in the media and the general public was far greater than that of Henri Bour, his main competitor. In other words, food companies would have found it difficult to do without Jean Trémolières' support, which also probably conditioned that of other important medical or scientific figures, such as Hugues Gounelle de Pontanel.

However, these tensions should not lead us to underestimate the fact that for a large proportion of the academics contacted by Robert Féron, the Foundation's project was embedded in the continuity of their previous collaborations with food companies and even vital to the realization of some of their research. Furthermore, several of the academics, such as Henri Bour and André François, shared the view that consumer associations and the media tended to exaggerate the dangers that the industrialization of food production would pose to health and to underestimate its benefits. They believed it was therefore the duty of academics to intervene in the public arena to rectify these erroneous discourses, which were likely to create unnecessary concerns among consumers, who were considered to be credulous. This scientistic stance was perfectly consistent with the food executives' project, which was indeed to use scientific and academic 
authority to challenge the supposedly dubious or misleading allegations of consumer associations.

\section{The Industry's Ascendency}

We will now look at how the Foundation was set up, from its official creation in 1974 through to the beginning of the 1980s. This was a period of trial and error, during which the Foundation's activities were reoriented: while they initially consisted exclusively in funding research, from 1978 onward they diversified in favor of activities oriented toward public relations. This evolution was the result of repeated discussions among members of the Foundation's bodies, which turned to the advantage of the food company executives and of the academics who supported their views.

\section{Supporting Research}

For the most part, the Foundation's actions initially consisted in funding research on nutrition. Between 1974 and 1976, the Foundation paid out 900,000 francs to research centers. The first approved funding was above all used to reward scientists who had agreed to join the Foundation's bodies. However, the level of funding was modest. Grants paid to postdoctoral researchers (50,000 francs per year per researcher) used up approximately half of the scientific budget. Subsidies for research projects were between 5,000 and 60,000 francs, which was little and mainly intended to supplement the financing of ongoing research paid for with public funds. Without greater financial resources, it therefore appeared that the Foundation had a limited capacity to influence the choice of research subjects in a way that could be useful to the food companies.

The search for new resources was a recurring concern for the Foundation's President. The Foundation's operating resources essentially relied on the fees paid by its industrial members. ${ }^{13}$ Contrary to what the food companies had initially hoped, the Foundation was not eligible for a recognition of "public utility", which would have enabled it to benefit from substantial tax advantages. Membership fees were gradually increased from 30,000 to 80,000 francs per year for the largest companies. Robert Féron did his utmost to persuade new companies to join the Foundation. At the time of its creation, the Foundation had a total of ten members. In 1976, eight additional companies joined the Foundation. Their numbers stagnated over the following years, with new memberships merely making up for defections. In constant francs, the Foundation's total budget remained small: it stabilized at approximately 500,000 francs per year at the end of the 1970s, compared to 407,000 francs in the year it was founded (see Table 4.3). The increase in the amount of fees received did not therefore make it possible to significantly increase its 
Table 4.3 Evolution in the Foundation's budget between 1975 and 1982

\begin{tabular}{lrrrr}
\hline Year & \multicolumn{1}{l}{1975} & \multicolumn{1}{l}{1977} & \multicolumn{1}{l}{1980} & \multicolumn{1}{l}{1982} \\
\hline Operation & $27.4 \%$ & $36.8 \%$ & $34.9 \%$ & $37.1 \%$ \\
Public relations & & $21.1 \%$ & $21.7 \%$ & $18.4 \%$ \\
Research subsidies and scholarships & $72.6 \%$ & $42.1 \%$ & $17.6 \%$ & $29.1 \%$ \\
Symposia & & & $12.7 \%$ & $10.3 \%$ \\
Foundation's award & & & $3.5 \%$ & $3.7 \%$ \\
Documentation & & & $1.3 \%$ & $1.4 \%$ \\
Sundry & 407,000 & 791,600 & 517,100 & 514,000 \\
Total budget (in 1975 francs) & & & & \\
\hline
\end{tabular}

Interpretation: 1980 aside, these budgets were provisional and do not represent actual expenditure.

scientific budget. Deeming the research funded by the Foundation to be costly, with limited returns, the food company executives decided to support a reorientation of its activities.

\section{A Turning Point in Communication}

A discussion on "the future of the Foundation" was put on the agenda of the Board of Directors meeting in April 1975. The President of the Foundation introduced the item as follows:

Should the foundation's activity be limited to research? However important and desirable it may be to aid research, it would seem necessary for it to be extended to activities of information. At present, such activities are carried out by people who are sometimes poorly qualified and not always well-intentioned.

A working group was put in charge of making more specific recommendations. During the first meeting of this group, Robert Féron presented the activities of the British Nutrition Foundation and the American Nutrition Foundation. Both had significant communication activities targeting the general public, including the organization of radio and television debates. For Féron, the Foundation needed to become a "central information point" capable of providing "a critical analysis of contemporary scientific matters relating to nutrition", while at the same time taking care to "never become involved in the controversies" raised by consumer associations. ${ }^{14}$ In January 1976, the working group submitted a memorandum setting out the actions it proposed: the creation of a monthly newsletter for members, the introduction of working groups on themes of interest to members, and finally the organization of information meetings and symposia open to an outside public.

These proposals were supported by the food companies, who wanted the Foundation to help them anticipate the issues that might be taken up 
by consumer associations and provide them with ready-made responses and the greater the pressure from the UFC, the stronger their support. In 1976, the UFC published a guide on food additives and advised consumers to avoid "processed" foodstuffs that contained colorants, preservatives, antioxidants, or flavor enhancers. ${ }^{15}$ It especially targeted colorants, deeming them to be unnecessary and calling for them to be boycotted.

Conversely, the academics were divided. Some of them maintained a scientistic stance: in the name of science, the Foundation's mission should be to fight misconceptions and exaggerations such as those supposedly propagated by consumer associations in relation to food additives. This was the position held by Henri Bour, who felt that the Foundation should combat the "untruths" that were appearing on a daily basis "in the press and on the airwaves" and "impose itself on public opinion and opinion-makers". Other academics such as Jean Trémolières and Hugues Gounelle de Pontanel were more hesitant on the issue of public relations: the Foundation's mission had to be to fund research and should not intervene in the public arena, especially on matters that were the object of scientific debate.

Initially, the position defended by Jean Trémolières and Hugues Gounelle de Pontanel prevailed. In April 1976, the only decision made was that of creating a monthly newsletter for members. However, three factors led to the balance of power evolving in favor of the food companies and of the academics who supported them. First of all, the food companies refined their arguments: actions of communication would not impede support for research, as they would contribute toward the emergence of new areas of research and encourage public authorities to finance them. In May 1977, during a meeting of the Board of Directors, René Jenny, CEO of Nestlé's subsidiary in France, explained that the aim of the Foundation should be "to encourage new research through public relations activities" and warned to not "put the cart before the horse". Secondly, Jean Trémolières died unexpectedly in July 1976: with his passing, Hugues Gounelle de Pontanel found himself isolated against the academics and food company executives who defended a scientistic line, leading him to express his desire to leave the Foundation. Finally, due to the increase in the number of members and the rise of membership fees, the Foundation's budget almost doubled between 1975 and 1977 (see Table 4.3). This initially made it possible to finance new activities without having to appropriate the funds earmarked for research support.

The shift toward a policy more in line with the expectations of the food companies was confirmed during the discussions that took place following a request from the Secretary of State for consumer affairs. In February 1975, she suggested that under her patronage, the Foundation should organize "a symposium bringing together consumers, academics, and food companies, in order to jointly examine, and where necessary demystify, a certain number of problems that were causing considerable 
commotion in the press ${ }^{16}$ ". Although she abandoned this project, the CEO of Nestle France and the Deputy Director of ILEC felt that the Foundation should organize this symposium, as it "corresponds precisely to what the manufacturers expect from the Foundation". In order to avoid the symposium turning into a confrontation between the food companies and consumer representatives, the Foundation's President proposed that consumers' opinions be collected by means of a survey. He asked one of France's biggest opinion poll companies, SOFRES, for a quote. The cost of the survey frightened both the academics and the food company executives, leading ILEC's Deputy Director to ask, for example, "whether there is not a disproportion between the 220,000 francs given to an opinion poll organization that will work for three months and the Foundation's research budget of 330,000 francs". The CEO of Nestlé France nevertheless supported this initiative, reasoning that since the symposium was a "public relations operation", it was vital that the survey be carried out by a reputable organization.

The financing of this survey set an important precedent: as of 1977 , the Board of Directors voted that every year a sum of 200,000 francs would be allocated to public relations actions. As stated in the minutes of a meeting of the Board of Directors in May 1977, this was in keeping "with the framework of the Foundation's realigned policy", which was not only to fund research but also to take part in public debate.

This realignment caused major tensions among the academics, as Gérard Debry, Chairman of the Foundation's Scientific Committee since Trémolières' death, explained in a letter to the President in June 1977: "The academics have the impression that the orientation [of the Foundation's activity] is increasingly turned towards using scientists to cover up the industry's wrongdoings". Some among them decided to distance themselves. In 1978 and 1979, Gérard Debry and Hugues Gounelle de Pontanel (then Vice President of the Foundation) resigned. They were replaced by leading figures who supported the directions the Foundation was taking: nutritionist Henri Dupin, who had taken Jean Trémolières' chair at the CNAM after his death, became Chairman of the Scientific Committee, and Henri Bour was appointed Vice President of the Foundation.

\section{Implementation of a "Realigned Policy"}

The Foundation's "realigned policy" was implemented by a new committee, the "Communication Group", formed in April 1978. Although it was made up equally of industry representatives and academics, there was clearly greater commitment from the former than from the latter. Only two academics regularly attended the meetings: Henri Dupin and Henri Bour.

The main activities developed by the Foundation between 1978 and 1982 were designed to increase its visibility, to extend and support its networks, and to influence the nutritional knowledge disseminated 
to certain professionals. As far as the first objective was concerned, the Communication Group's first initiative was to organize "minicommunication symposia", the main purpose of which was to encourage food companies to join the Foundation. Seven of these were organized before being cancelled due to a lack of participants. Another initiative was more successful. In 1978, the Foundation's new President, a pediatrician and professor of medicine, suggested the creation of an annual award, to be presented by a high-profile personality in front of an assembly of journalists and a carefully selected audience, in order to "seek maximum promotional action in favor of the foundation". The first year was considered a success. One hundred and fifty people attended the ceremony, in the presence of the Secretary of State for research, to whom the President of the Foundation was at that time an advisor. Not only did the award ceremony increase the Foundation's visibility, but it also made it possible to reward or even recruit academics, executives from research organizations, and senior civil servants into its bodies at a modest cost.

Since 1979, the Foundation had also been organizing events aimed at bringing academics and food companies together on targeted subjects. These "scientific" symposia, which covered subjects that were a matter of controversy at that time (such as fats, sweeteners, additives, dietary guidelines, etc.) were more successful than the "communication" symposia. In 1981, the Foundation decided to devote more resources to these events. In 1982, two scientific symposia were organized, lasting two and three days, respectively, and involving both presentations by academics and round tables with food companies.

As the Communication Group focused on the issue of the Foundation's reputation and on the organization of exchanges between academics and food companies, the work of informing and raising the awareness of "intermediary circles" became secondary. As of 1981, the members of the Communication Group were to repeatedly discuss this issue. Unlike its British and American counterparts, the Foundation did not have the resources to carry out large-scale communication operations. The decision was therefore taken to focus on "relay" professions, i.e., on professional groups capable of relaying the Foundation's messages on the safety and the nutritional soundness of industrial foodstuffs to a wider audience. Not only would this be less expensive, but such groups were considered to be more credible to the public than the food companies and more receptive to science-based messages. They would therefore permit a more effective dissemination of the Foundation's messages. At a symposium organized by the Foundation in 1980, Henri Dupin explained:

It is obvious that there is a huge interest in nutrition. We have to see which group of people is best placed to provide information. Some groups have been mentioned today: teachers and social workers. These groups must obviously be credible. As things stand, manufacturers cannot fill this role because people do not trust them. 
The Foundation initially decided to focus on three professions: social and family counseling, pharmacy, and journalism. It abandoned the idea of producing and disseminating content for teachers, partly due to the cost of such an operation and partly because another organization funded by the agri-food industry had already begun to do this. However, it did not cease all actions targeting educational circles: in 1982, the Communication Group defended the idea that "the role of the FFN could be to give an opinion on the various documents and books published on nutrition and food", including school and university textbooks - given that nutrition education had become compulsory in medical schools in 1980.

The reorientation of the Foundation's activities in 1977-1978 had a very clear impact on its budget (see Table 4.3). Operating and public relations expenditure amounted to more than half of the Foundation's budget - more than two thirds if one includes expenditure relating to the organization of symposia and the cost of the Foundation's award, which were for communication purposes. On the other hand, the level of subsidies paid to research teams fell sharply: in constant francs, it fell by half between 1975 and 1982. In 1978, the Foundation even decided to stop awarding grants (considered to be too costly) to young researchers and to only allow funding for research teams. This led to disappointment among the academics, who felt that public funds for nutrition research were insufficient and that the Foundation should do more to support research. But given the Foundation's reduced resources and the now significant level of operating and public relations expenses, this remained no more than wishful thinking.

\section{Conclusion: Capturing and Neutralizing Matters of Public Debate}

The French Nutrition Foundation, as it operated from the early 1980s onward, was the result of a process that can be broken down into three stages. The first (1972-1973) was the mobilization of a small number of large agri-food companies to create an organization ready to fight consumer associations on their own ground, that of information. To this end, although it was dependent on corporate funding, this new organization had to appear to be formally independent of the companies involved. The food company executives who created the Foundation felt that they could not themselves intervene on public health issues, as they would not be credible and would come across as simply wanting to defend their products. Only recognized academics could develop positions that would be authoritative and disqualify what were deemed to be the "irrational" positions of consumer associations. A specific socio-historical context, marked by major protests against corporations and a strengthening of regulations protecting consumers, led some food companies to believe they could no longer defend themselves on their own, nor do so in their own name. 
This context has benefited the academics that these manufacturers wished to enroll, with some of them attempting to negotiate their support. This second stage (1973-1976) was initiated by Jean Trémolières, who took advantage of his central position in the field of nutrition in France and of his popularity with the general public. He succeeded in obtaining an increase in the Foundation's budget, which was mainly used to fund research projects and grants. His death triggered a third stage (19761982): the food company executives took advantage of the existing dissensions between academics and the attachment of several among them to a scientistic conception according to which the Foundation should intervene in the public arena to counter misconceptions about food and refocused the Foundation's activity on scientific monitoring and public relations.

Between 1972 and 1982, the Foundation's missions evolved. At first, they were essentially oriented toward the funding of research, and it was thus seen as a philanthropic organization. But as of 1976, its activities became more like those of a think tank, designed to influence public debate. The French Nutrition Foundation can therefore be analyzed as a negotiated order, in as much as it was the result of successive negotiations, the outcome of which depended both on the power relationship between the protagonists and on their commitment. In this case, business circles ended up imposing the rules of the game. The only academics to remain loyal to the FFN were those who agreed to play by these rules and accept their consequences, giving up a certain amount of their professional autonomy in the hope of a greater public impact or of accessing the food companies' data. While early on some academics voiced their concerns about the FFN's independence from the food companies, most of the others followed an exit strategy. Once it was clear the FFN would not operate primarily as a funding agency, the risk of compromising their independence exceeded the benefits to be gained from their participation. These negotiations illustrate the complicated arrangements between academics and corporate funders, which cannot be described simply in terms of "selling out" and "buying" science but must be assessed in each case according to specific professional and institutional parameters.

The case of the FFN testifies to the protean mobilization of business circles in the 1970s, which resulted in the creation of new organizations that aim to promote corporate interests under the guise of science and expertise (Plehwe 2014; Miller and Dinan 2015). Unlike the definitions often used to characterize think tanks, their action is not necessarily directed toward public authorities but can also target other audiences: academics, journalists, teachers, health-care professionals, social workers, etc. Even more than the content of public policies, it is the social world and its materiality that they aim to transform over the long term, by attempting to modify the categories through which we perceive and analyze it. These 


\section{2}

organizations operate under a wide range of legal statutes or names (institute, foundation, observatory, research center, etc.) which sometimes change over the course of their existence: in 1990, the FFN thus became an "institute", before presenting itself as an endowment "fund" in 2010, and as a "foundation" again in 2021. Therefore, while these organizations have certain features in common, as far as their articles of association are concerned, they are characterized by a "structural blurriness" which makes them all the less identifiable by the public (Medvetz 2012).

Considering its small budget, modest size, and the few staff assigned to it, one might wonder about the point of studying an organization such as the FFN and the influence it might have had. Yet more than forty-five years after its creation, it still exists and has had a range of legal statuses as it has grown and diversified its activities - carrying out studies at the government's request, for example. Taken in isolation, the FFN has probably not had any decisive impact on foodrelated debates and public policies. But at the same time, FFN member companies have founded or supported other similar organizations in France and other Western countries, that sometimes operate on a global scale - such as the International Life Sciences Institute (ILSI). For example, Nestle has not only played an active role in the FFN; it also created its own corporate foundation - the Nestlé Foundation (in 1966) - and its own research center, the Nestlé Nutrition Institute (established in 1981). It also participates as a sustaining member in the British Nutrition Foundation (1967), the ILSI (1978), the International Food Information Council (1985), and the European Food Information Council (1995).

Just like the FFN, and with the exception of the largest among them, these organizations operate with modest resources and essentially focus on media and scientific monitoring, communication activities, or the organization of events that help them to maintain their networks. In other words, think tanks in the food industry help to disseminate knowledge that reduces food problems to their technical dimensions, capturing and neutralizing matters of public debate. The moderate stance they take against the "alarmist" discourse of consumer associations or the media makes it possible to pass off the indecision and neutralization of critics as the apparent objectivity of a science of synthesis, which is reminiscent of the production of ignorance strategies implemented in other industrial sectors (Markowitz and Rosner 2002; Proctor 2011; Vogel 2013). Taking advantage of or even fueling scientific controversies, they can prolong uncertainty on the most sensitive subjects and oppose attempts to regulate their activities. To understand the influence exerted through them by agri-food companies, it is the combined work of all of these organizations that needs to be studied, so as to grasp the entire field (Medvetz 2012) or network (Plehwe 2014) of relationships that they cover and which make them effective over the long term. 


\section{Notes}

1 The research on which this chapter is based was funded by the Agence nationale de la recherche (French National Research Agency, ANR-18-CE260016). Thanks to Christopher Hinton for his translating assistance.

2 In 1970, Ralph Nader published The Chemical Feast, a report which denounced the harmful consequences of industrializing food production. It was translated and published in French in 1972.

3 Que Choisir? no. 78, July 1973.

4 Ibid.

5 ILEC was founded in 1959 on the initiative of the CEO of Astra, a subsidiary of the Unilever group in the field of cooking oils and margarines. Initially, the companies that were members of ILEC essentially belonged to the food, toiletries, and cosmetics sectors (Bulletin de l'ILEC, no. 403, 2009).

6 Subsidiaries of the same group are considered here to be part of the same company.

7 Handwritten notes, October 1972.

8 At the time, use of the term "foundation" was not regulated in France. The only regulated term was "foundation recognized of public utility", which gave rise to special tax advantages.

9 Except where indicated, all of the quotes in this chapter are taken from FFAS archives.

10 The Institut national d'hygiène, a leading institution for public research in the field of medicine and public health, became the Institut national de la santé et de la recherche médicale (INSERM) in 1964.

11 According to an undated GLN memorandum.

12 According to a 1973 ILEC memorandum.

13 The Foundation was provided with free premises by ILEC.

14 According to the minutes of the working group's first meeting in October 1975.

15 Que Choisir?, no. 106, April 1976.

16 Lettre d'information from the Foundation, May 1976.

\section{References}

Abbott, Andrew Delano. 2001. Time Matters: On Theory and Method. Chicago: University of Chicago Press.

Belasco, Warren James. 1989. Appetite for Change: How the Counterculture Took on the Food Industry, 1966-1988. New York: Pantheon Books.

Besson, Danielle. 2008. "Le repas depuis 45 ans: moins de produits frais, plus de plats préparés”. INSEE Première 1208. www.epsilon.insee.fr/jspui/handle/1/ 41.

Blumer, Herbert. 1962. "Society as Symbolic Interaction". In Human Behavior and Social Processes, edited by Arnold M. Rose, 179-192. Boston: Houghton-Mifflin.

Bonneuil, Christophe, and Thomas Frédéric. 2009. Gènes, pouvoirs et profits. Recherche publique et régimes de production des savoirs de Mendel aux OGM. Versailles: Quae.

Boudia, Soraya, and Nathalie Jas. 2019. Gouverner un monde toxique. Versailles: Quae. 


\section{Depecker, Déplaude, and Larchet}

Callon, Michel, and John Law. 1982. "On Interests and Their Transformation: Enrolment and Counter-enrolment". Social Studies of Science 12: 615-625.

Caré, Sébastien. 2010. Les libertariens aux États-Unis. Sociologie d'un mouvement asocial. Rennes: Presses Universitaire de Rennes.

Chamayou, Grégoire. 2018. La société ingouvernable. Une généalogie du libéralisme autoritaire. Paris: La Fabrique Éditions.

Chatriot, Alain. 2006. "Consumers' Association and the State: Protection and Defense of the Consumer in France, 1950-2000". In The Expert Consumer: Associations and Professionals in Consumer Society, edited by Alain Chatriot, Marie-Emmanuelle Chessel, and Matthew Hilton, 123-136. London: Ashgate.

Daumas, Jean-Claude. 2006. "Consommation de masse et grande distribution. Une révolution permanente (1957-2005)". Vingtième Siècle. Revue D’histoire 91(3): 57-76. https://doi.org/10.3917/ving.091.76.

Degreef, Filip. 2019. "What's the Deal with These Strange Substances in Our Food? The Representation of Food Additives by Belgian Consumer Organizations, 1960-1995". Food and Foodways 27(1-2): 144-163. https://doi.org/10.1080/ 07409710.2019 .1591625$.

Denord, François. 2002. "Le prophète, le pèlerin et le missionnaire. La circulation internationale du néo-libéralisme et ses acteurs". Actes de la Recherche en Sciences Sociales 145: 9-20. https://doi.org/10.3406/arss.2002.2794.

Depecker, Thomas, and Marc-Olivier Déplaude. 2017. "Information et désinformation des consommateurs. La constitution d'un répertoire d'action consumériste dans les années 1960”. Terrains \& Travaux 31: 21-44. https:// doi.org/10.3917/tt.031.0021.

Fine, Gary Alan. 1984. "Negotiated Orders and Organizational Cultures". Annual Review of Sociology 10(1): 239-262. https://doi.org/10.1146/annurev. so.10.080184.001323.

James, Simon. 1993. “The Idea Brokers: The Impact of Think Tanks on British Government”. Public Administration 71(4): 491-506. https://doi.org/10.1111/ j.1467-9299.1993.tb00988.x.

Markowitz, Gerald, and David Rosner. 2002. Deceit and Denial: The Deadly Politics of Industrial Pollution. Berkeley: University of California Press.

McCright, Aaron M., and Riley E. Dunlap. 2003. "Defeating Kyoto: The Conservative Movement's Impact on U.S. Climate Change Policy". Social Problems 50(3): 348-373. https://doi.org/10.1525/sp.2003.50.3.348.

McLevey, John. 2015. "Understanding Policy Research in Liminal Spaces: Think Tank Responses to Diverging Principles of Legitimacy". Social Studies of Science 45(2): 270-293. https://doi.org/10.1177\%2F0306312715575054.

Medvetz, Thomas. 2012. Think Tanks in America. Chicago: University of Chicago Press.

Meyer, David S., and Suzanne Staggenborg. 1996. "Movements, Countermovements, and the Structure of Political Opportunity". American Journal of Sociology 101(6): 1628-1660. https://doi.org/10.1086/230869.

Miller, David, and William Dinan. 2015. "Resisting Meaningful Action on Climate Change: Think Tanks, 'Merchants of Doubt' and the 'Corporate Capture' of Sustainable Development”. In The Routledge Handbook of Environment and Communication, edited by Anders Hansen and J. Robert Cox, 96-110. London: Routledge. https://doi.org/10.4324/9781315887586.ch7.

Oreskes, Naomi, and Erik Conway. 2010. Merchants of Doubt: How a Handful of Scientists Obscured the Truth on Issues from Tobacco Smoke to Global Warming. New York: Bloomsbury. 
Pautz, Hartwig. 2012. Think-Tanks, Social Democracy and Social Policy. London: Palgrave Macmillan.

Pinto, Louis. 2018. L'invention du consommateur. Sur la légitimité d'un marché. Paris: PUF.

Plehwe, Dieter. 2014. “Think Tank Networks and the Knowledge-Interest Nexus: The Case of Climate Change". Critical Policy Studies 8(1): 101-115. https:// doi.org/10.1080/19460171.2014.883859.

Plehwe, Dieter. 2015. "The Politics of Policy Think-Tanks: Organizing Expertise, Legitimacy and Counter-Expertise in Policy Networks". In Handbook of Critical Policy Studies, edited by Frank Fischer, Douglas Torgerson, Anna Durnová, and Michael Orsini, 358-379. Cheltenham: Edward Elgard. https:// doi.org/10.4337/9781783472352.00028.

Plehwe, Dieter, Quinn Slobodian, and Philip Mirowski (eds). 2020. Nine Lives of Neoliberalism. London, New York: Verso.

Proctor, Robert N. 2011. Golden Holocaust: Origins of the Cigarette Catastrophe and the Case for Abolition. Berkeley: University of California Press.

Schlesinger, Philip, and Frédéric Junqua. 2012. "Expertise, politiques publiques et économie créative : le cas britannique". Actes de la Recherche en Sciences Sociales 193: 80-95. https://doi.org/10.3917/arss.193.0080.

Schwartz, Antoine. 2010. "Les think tanks et la consolidation d'une vision économique du social”. Informations Sociales 157: 60-68. https://doi.org/ 10.3917/inso.157.0060.

Shaw, Sara E., Jill Russell, Wayne Parsons, and Trisha Greenhalgh. 2015. “The View from Nowhere? How Think Tanks Work to Shape Health Policy". Critical Policy Studies 9(1): 58-77. https://doi.org/10.1080/19460171.2014.964278.

Stahl, Jason. 2016. Right Moves: The Conservative Think Tank in American Political Culture since 1945. Chapel Hill: University of North Carolina Press.

Stone, Diane. 1996. Capturing the Political Imagination: Think Tanks and the Policy Process. London: Frank Cass.

Stone, Diane. 2007. "Recycling Bins, Garbage Cans or Think Tanks? Three Myths Regarding Policy Analysis Institutes". Public Administration 85(2): 259-278. https://doi.org/10.1111/j.1467-9299.2007.00649.x.

Stone, Diane. 2015. "Think Tanks". In International Encyclopedia of the Social \& Behavioral Sciences, second edition, edited by James D. Wright, 294-299. Oxford: Elsevier.

Strauss, Anselm, Leonard Schatzman, Danuta Ehrlich, Rue Bucher, and Melvin Sabshin. 1963. "The Hospital and Its Negotiated Order”. In The Hospital in Modern Society, edited by Eliot Freidson, 147-169. New York: Free Press.

Tchilingirian, Jordan Soukias. 2018. "Producing Knowledge, Producing Credibility: British Think-Tank Researchers and the Construction of Policy Reports”. International Journal of Politics, Culture, and Society 31(2): 161178. https://doi.org/10.1007/s10767-018-9280-3.

Vogel, David. 1983. "The Power of Business in America: A Re-appraisal”. British Journal of Political Science 13(1): 19-43. https://doi.org/10.1017/ S0007123400003124.

Vogel, Sarah A. 2013. Is It Safe? BPA and the Struggle to Define the Safety of Chemicals. Berkeley: University of California Press.

Weaver, Kent R. 1989. “The Changing World of Think Tanks". PS: Political Science \& Politics 22(3): 563-578. https://doi.org/10.2307/419623. 